\title{
THE EFFECT OF OBESITY AND OTHER FACTORS TOWARDS ON THE INCREASED RISK OF RHEUMATISM IN INDONESIA (ANALYSIS OF IFLS 2014)
}

\author{
Nuraini, Amrina Rosyada* \\ Public Health Study Program, Faculty of Public Health, Sriwijaya University, Jl. Palembang-Prabumulih \\ KM 32 Ogan Ilir, 30662, Indonesia
}

\begin{abstract}
The number of people with rheumatism worldwide has reached 355 million, and this is estimated by 2025, suggesting that more than $25 \%$ will experience paralysis. This study aims to determine obesity and other factors related to the increased risk of rheumatic diseases in Indonesia, the method used was data analysis using a complex sample survey. It used 2014 IFLS data and a cross sectional study design, as well as a multistage random sampling with a total of 29,106 respondents, and the results showed that the prevalence of rheumatic disease in Indonesia was $5.2 \%$ in 2014. The most dominant and unmodifiable variable that influenced incidence was gender (PR=1.686; 95\% CI=1.488-1.910). Meanwhile, obesity is the most dominant and modifying variable that influences the incidence of rheumatic disease (PR $=1.630 ; 95 \%$ $C I=1.433-1.855)$. Factors that are simultaneously related to the increased risk of rheumatic diseases include age, gender, education, physical activity, protein consumption, obesity, and accident history. Considering the results, patients need to eat healthy and low purine foods, as well as implementing other healthy lifestyles such as appropriate, adequate, and regular physical activities in order to reduce the risk of rheumatism.
\end{abstract}

Keywords: gender, obesity, rheumatism

\begin{abstract}
ABSTRAK
Penderita rematik di seluruh dunia telah mencapai angka 355 juta jiwa. Diperkirakan angka ini terus meningkat hingga tahun 2025 dengan indikasi lebih dari $25 \%$ akan mengalami kelumpuhan. Penelitian ini bertujuan mengetahui faktor yang berhubungan dengan peningkatan risiko penyakit rematik di Indonesia. Penelitian ini menggunakan data IFLS tahun 2014 dan menggunakan desain studi cross sectional. Pengambilan sampel menggunakan multistage random sampling dengan sampel sebesar 29.106 responden dan analisis data menggunakan analisis complex sample. Hasil penelitian menunjukkan bahwa prevalensi penyakit rematik di Indonesia tahun 2014 yaitu 5,2\%. Variabel paling dominan dan tidak dapat dimodifikasi yang berpengaruh pada kejadian penyakit rematik adalah jenis kelamin $(\mathrm{PR}=1,686 ; 95 \% \mathrm{CI}=1,488-1,910)$. Sedangkan variabel paling dominan dan dapat dimodifikasi yang berpengaruh pada kejadian penyakit rematik adalah obesitas $(\mathrm{PR}=1,630 ; 95 \% \mathrm{CI}=1,433-1,855)$. Faktor yang secara bersamaan berhubungan dengan peningkatan risiko penyakit rematik antara lain umur, jenis kelamin, pendidikan, aktivitas fisik, konsumsi protein, obesitas, dan riwayat kecelakaan. Mengonsumsi makanan sehat dan rendah purin, serta melakukan penerapan gaya hidup sehat lain seperti aktivitas fisik yang sesuai, cukup, dan teratur. Skrining pun perlu dilakukan guna mewaspadai gejala awal timbulnya rematik.
\end{abstract}

Kata kunci: jenis kelamin, obesitas, rematik 


\section{Introduction}

Increasing Life Expectancy (UHH) is related to the rise in the number of elderly people from yearly. In Indonesia, for almost five decades (1971-2017), the percentage of older people was doubled to 8.97 percent or around 23.4 million. Furthermore, this increase has consequences for national development since it is related to the productivity and quality of elderly life, which tend to decline. In terms of health, people also have decreased anatomical and immune function in warding off all kinds of diseases. As a result of this, the prevalence of non-communicable diseases among older people is currently increasing. ${ }^{1}$ The aging process has impacts various life aspects, both social, economic, and health. Based on a health aspect, older people are more susceptible to various physical complaints, both due to natural factors and disease. There are 10 diseases which are dominated by non-communicable, chronic, and degenerative often suffered by elderly people in 2013 these include arthritis or rheumatism with a prevalence of 45\% in the 55-64 years age group, $51.9 \%$ in the $65-74$ years age group, and $54.8 \%$ in the $\geq 75$ years age group. ${ }^{2}$

In the world, rheumatic joints are the most common musculoskeletal diseases, and people who suffer from such disease have reached 355 million worldwide, which means that 1 in 6 people in the world suffers from rheumatoid. ${ }^{3}$ It is estimated that this number will continue to increase until 2025 with an indication that more than 25\% will experience paralysis. Furthermore, The trend of rheumatism prevalence in Indonesia has decreased to $24.7 \%$ based on interviews in 2013 . This prevalence was lower by $30.3 \%$ than in $2007 .{ }^{4}$ Therefore, this is assumed to be the possibility of better population behavior, such as exercise and diet. In this case, further analysis is needed. ${ }^{2}$

The exact cause of rheumatism has not been determined, but several factors increase uric acid levels in the body. ${ }^{3}$ Risk of rheumatism is higher with age, and women are also more prone to arthritis than men, with a factor of $60 \% .{ }^{5}$ Furthermore, the prevalence of joint disease based on interviews diagnosed by health workers increases along with age, as well as diagnosed with symptoms. The highest prevalence was at the age of $\geq 75$ years old ( $33 \%$ and $54.8 \%)$. Meanwhile, it was reported to be higher in women (13.4\%) than men $(10.3 \%)$ as well as diagnosed with symptoms in women $(27.5 \%)$ which, was higher than men $(21.8 \%){ }^{2} \mathrm{~A}$ study conducted from the Mayo clinic in the United States also showed that between 1995-2005, women with rheumatism reached 54,000-100,000 people, while in men only 29,000 out of 100,000 people. ${ }^{4}$ Furthermore, other triggering factors for rheumatism are work, food, hormones, obesity, injury, psychological and free radicals. Putri (2018) also showed that in 2017 at Jorong Padang Bintungan in the working area of Koto Baru Community Health Center, Dharmasraya Regency, there was a significant association between physical activity and the incidence of rheumatism in elderly people. ${ }^{5}$ Ahdaniar (year) also showed that the variable of physical activity level and the incidence of rheumatic 
disease in the elderly people was $\mathrm{P}=0.021(\mathrm{P}<0.05)$, which means that there is a significant relationship between physical activity and the incidence of rheumatism in the elderly people. ${ }^{6,7}$ Based on the data and information, this study aims to determine obesity and the other factors related to the increased risk of rheumatic disease at age $\geq 15$ years in Indonesia.

\section{Method}

The method used was a cross-sectional study design, and the population consists of respondents from 13 provinces in Indonesia that successfully passed the census and fulfilled the inclusion and exclusion criteria. Sampling was conducted using a multistage random technique. Sampling in IFLS is carried out in a manner gradually, where from the 13 provinces, 321 enumeration areas were selected at random. The sample frame used is based on (Social Survey and National Economy) SUSENAS 1993 which, includes 60,000 households. The inclusion criteria which includes IFLS 2014 respondents aged $\geq 15$ years and exclusion criteria which include missing data and pregnant women, therefore a total of 29,106 respondents were obtained. Furthermore, the dependent variable was a rheumatic disease, while the independent variables consisted of age, gender, education, work status, physical activity, protein consumption, obesity, and accident history. In addition, the books used in this study consist of book K (age and gender), book 3A (education and work), and book 3B (rheumatism, physical activity, protein consumption, and accident history), as well as US book (obesity). Physical activity measure uses total score physical activity daily (activities physical weight, physical activity moderate, and on foot), that done in 10 minutes consecutive for 7 days last then categorized based on value interval SD. Protein consumption measure use frequency consumption protein (fish egg, meat) respondents in last one week then categorized based on category from Food Frequency Questionnaire (FFQ). History accident that maybe ever respondent naturally good accident traffic nor fall down. The data were analyzed using univariate and bivariate analysis with simple logistic regression as well as multivariate analysis using multiple logistic regression tests with predictive factor models. This article has passed the ethical review by the Health Research Ethics Commission of the Faculty of Public Health, Sriwijaya University with number 99 / UN9.1.10 / KKE / 2019

\section{Results}

Data analysis was not conducted on all IFLS 2014 respondents that successfully fulfilled the census, by 50,148. The inclusion and exclusion criteria are used in this study, and 29,106 respondents fulfilled these criteria, meanwhile the missing data with the inclusion and exclusion criteria are 21,042 . Therefore, $41.9 \%$ of data analyzed. The IFLS 2014 data showed that there were more respondents without rheumatic disease by $94.8 \%$. The majority consist of female respondents (50.6\%), had a low level of education (57.1\%), working status (69.0\%), light physical activity 
(85.4\%), rare protein intake $(90.3 \%)$, was not obese $(79.7 \%)$, and had no accidents history $(70.9 \%)$ (Table 1). The mean (median) age of the respondents is 35 years, with the lowest and highest age been 15 and 101 years respectively (Table 2 ).

Table 1: Respondents Frequency Distribution Based on Respondent Characteristics

\begin{tabular}{|c|c|c|}
\hline Variable & Frequency & Percentage \\
\hline \multicolumn{3}{|l|}{ Rheumatic Diseases } \\
\hline Yes & 1519 & $5.2 \%$ \\
\hline No & 27587 & $94,8 \%$ \\
\hline \multicolumn{3}{|l|}{ Gender } \\
\hline Female & 14729 & $50.6 \%$ \\
\hline Male & 14377 & $49.4 \%$ \\
\hline \multicolumn{3}{|l|}{ Education } \\
\hline Low (<Senior High School) & 16634 & $57.1 \%$ \\
\hline High ( $\geq$ Senior High School) & 12472 & $42.9 \%$ \\
\hline \multicolumn{3}{|l|}{ Job Status } \\
\hline Work & 20069 & $69.0 \%$ \\
\hline Does not work & 9037 & $31.0 \%$ \\
\hline \multicolumn{3}{|l|}{ Physical Activity } \\
\hline Heavy (113-168) & 524 & $1.8 \%$ \\
\hline Moderate (56-112) & 3730 & $12.8 \%$ \\
\hline Light $(0-55)$ & 24852 & $85.4 \%$ \\
\hline \multicolumn{3}{|l|}{ Protein Consumption } \\
\hline Often ( $\geq 3$ times) & 1877 & $6.4 \%$ \\
\hline Seldom (1-2 times) & 26273 & $90.3 \%$ \\
\hline Never & 956 & $3.3 \%$ \\
\hline \multicolumn{3}{|l|}{ Obesity } \\
\hline Obesity & 5906 & $20.3 \%$ \\
\hline Not Obesity & 23200 & $79.7 \%$ \\
\hline \multicolumn{3}{|l|}{ Accident History } \\
\hline Yes & 8474 & $29.1 \%$ \\
\hline Not & 20632 & $70.9 \%$ \\
\hline
\end{tabular}

Table 2. Respondents Frequency Distribution based on Age

\begin{tabular}{ccccc}
\hline Variable & Mean & Median & $\begin{array}{c}\text { Standard } \\
\text { Deviation }\end{array}$ & Min - Max \\
\hline Age (Years Old) & 36.70 & 35 & 14.378 & $15-101$ \\
\hline
\end{tabular}

The results of the bivariate analysis showed that 6 variables were related to an increased risk of rheumatic diseases, including gender with p-value of $<0.0001$ and PR of 1.632 (95\% CI = 1.459-1.852), education with p-value of $<0.0001$ and $\mathrm{PR}$ of 2.626 (95\% CI $=2.290-3.010)$, job status with a p-value of 0.048 and $\mathrm{PR}$ of $0.886(95 \% \mathrm{CI}=0.787-0.999)$, physical activity with a pvalue of 0.002 and PR of $1.299(95 \% \mathrm{CI}=1.101-1.532)$, obesity with a p-value of $<0.0001$ and a PR of $1.826(95 \% \mathrm{CI}=1.614-2.067)$ as shown in (Table 3$)$, as well as age variable with p-value of $<0.0001$ and PR of $1.057(95 \% \mathrm{CI}=1.053-1.061)$ as shown in (Table 4). 
Table 3. Relationship of Affecting Factors with the Incidence of Rheumatic Disease

\begin{tabular}{|c|c|c|c|c|c|c|c|c|}
\hline \multirow{3}{*}{ Variable } & \multicolumn{4}{|c|}{ Rheumatic Diseases } & \multirow{2}{*}{\multicolumn{2}{|c|}{ Total }} & \multirow{3}{*}{ P-value } & \multirow{3}{*}{ PR (95\% CI) } \\
\hline & \multicolumn{2}{|c|}{ Yes } & \multicolumn{2}{|c|}{ No } & & & & \\
\hline & $\mathbf{n}$ & $\%$ & $\mathbf{n}$ & $\%$ & $\mathbf{n}$ & $\%$ & & \\
\hline \multicolumn{9}{|l|}{ Gender } \\
\hline Female & 942 & 6.4 & 13787 & 93.6 & 14729 & 100 & \multirow[t]{2}{*}{$<0.0001$} & 1.632 \\
\hline Male & 578 & 4 & 13799 & 93 & 1437 & 100 & & $(1.459-1.825)$ \\
\hline \multicolumn{9}{|l|}{ Education } \\
\hline Low (<Senior High School) & 1170 & 7 & 15464 & 93 & 16634 & 100 & \multirow[t]{2}{*}{$<0.0001$} & 2.626 \\
\hline High ( $\geq$ Senior High School) & 349 & 2.8 & 12123 & 97.2 & 12472 & 100 & & $(2.290-3.010)$ \\
\hline \multicolumn{9}{|l|}{ Job Status } \\
\hline Work & 1009 & 5 & 19060 & 95 & 20069 & 100 & \multirow[t]{2}{*}{0.048} & 0.886 \\
\hline Does not work & 510 & 5.6 & 8527 & 94.4 & 8527 & 100 & & $(0.787-0.999)$ \\
\hline \multicolumn{8}{|l|}{ Physical Activity } & 1.038 \\
\hline Heavy (113-168) & 27 & 5.2 & 497 & 94.8 & 524 & 100 & 0.869 & $(0.667-1.615)$ \\
\hline Moderate (56-112) & 240 & 6.4 & 3490 & 93.6 & 3730 & 100 & \multirow[t]{2}{*}{0.002} & 1.299 \\
\hline Light (0-55) & 1252 & 5.0 & 23600 & 95.0 & 24852 & 100 & & $(1.101-1.532)$ \\
\hline \multicolumn{8}{|l|}{ Protein Consumption } & 0.880 \\
\hline Often ( $\geq 3$ times) & 105 & 5.6 & 772 & 94.4 & 1877 & 100 & 0.456 & $(0.627-1.233)$ \\
\hline Seldom (1-2 times) & 1354 & 5.2 & 24919 & 94.8 & 26273 & 100 & \multirow[t]{2}{*}{0.140} & 0.805 \\
\hline Never & 60 & 6.3 & 896 & 93.7 & 956 & 100 & & $(0.604-1.074)$ \\
\hline \multicolumn{9}{|l|}{ Obesity } \\
\hline Obesity & 470 & 8 & 5436 & 92 & 5906 & 100 & \multirow[t]{2}{*}{$<0.0001$} & 1.826 \\
\hline Not Obesity & 1049 & 4.5 & 22151 & 95.5 & 23200 & 100 & & $(1.614-2.067)$ \\
\hline \multicolumn{9}{|l|}{ Accident History } \\
\hline Yes & 461 & 5.4 & 8013 & 94.6 & 8474 & 100 & \multirow[t]{2}{*}{0.341} & 1.064 \\
\hline Not & 1058 & 5.1 & 19574 & 94.9 & 20632 & 100 & & $(0.936-1.209)$ \\
\hline
\end{tabular}

Table 4. The Relationship between Age and the Incidence of Rheumatic Disease

\begin{tabular}{cccc}
\hline Variable & Rheumatic Diseases & \multirow{2}{*}{ P-value } & \multirow{2}{*}{ PR (95\% CI) } \\
\cline { 2 - 3 } & Mean & & $<0.0001$ \\
\hline Age (Years Old) & 39.22 & $1.057(1.053-1.061)$ \\
\hline
\end{tabular}

The final model of multivariate analysis shows that the variables which are significantly related to an increased risk of rheumatic disease are age, gender, education, physical activity, protein consumption, obesity, and accident history. Furthermore, the analysis showed that the most dominant and unmodifiable variable with an effect towards the increased risk of rheumatic disease was gender. The results showed that the gender variable with a PR value of 1,686 (95\% CI: 1.4881.910), which means the female respondents have a 1.686 times greater chance to suffer from the rheumatic disease than male after being controlled by variables of age, education, physical activity, protein consumption, obesity, and accident history. In the general population, it is believed that $95 \%$ of female respondents are at risk of suffering from rheumatism ranging from 1.488 to 1.910 compared to males. Meanwhile, the most dominant and modifiable variable that affects the increased risk of rheumatic disease is obesity. The results of the analysis showed that the obesity variable has a PR value of 1.630 (95\% CI: 1.433-1.855), which means that obese respondents had a 1.630 times greater risk of rheumatic disease compared to non obese respondents after being controlled by variables of age, gender, education, physical activity, protein consumption, and accidents history. In the general population, it is believed that $95 \%$ of obese respondents have a risk 
of suffering from rheumatism ranging from 1,433 to 1,855 compared to nonobese respondents (Table 5).

Table 5: Multivariate Analysis of Factors Affecting the Incidence of Rheumatic Disease

\begin{tabular}{|c|c|c|c|c|}
\hline \multirow[t]{2}{*}{ Variable } & \multicolumn{2}{|r|}{ Modeling I } & \multicolumn{2}{|c|}{ Modeling II } \\
\hline & P-value & $\mathrm{RR}_{\mathrm{c}}(95 \% \mathrm{CI})$ & P-value & $P_{\mathrm{a}}(95 \% \mathrm{CI})$ \\
\hline Age & $<0.0001$ & $1.056(1.052-1.060)$ & $<0.0001$ & $1.056(1.052-1.060)$ \\
\hline \multicolumn{5}{|l|}{ Gender } \\
\hline \multicolumn{5}{|l|}{ Male* } \\
\hline Female & $<0.0001$ & $1.663(1.473-1.877)$ & $<0.0001$ & $1.686(1.488-1.910)$ \\
\hline \multicolumn{5}{|l|}{ Education } \\
\hline \multicolumn{5}{|l|}{ High* } \\
\hline Low & $<0.0001$ & $1.666(1.440-1.927)$ & $<0.0001$ & $1.663(1.438-1.924)$ \\
\hline Job Status & & & - & - \\
\hline \multicolumn{5}{|l|}{ Does not work* } \\
\hline Work & $0,375^{+}$ & $0.946(0.838-1.069)$ & & \\
\hline \multicolumn{5}{|l|}{ Physical Activity } \\
\hline \multicolumn{5}{|l|}{ Light* } \\
\hline Moderate & 0.382 & $1.232(0.771-1.970)$ & 0.402 & $1.220(0.765-1.947)$ \\
\hline Heavy & $<0.0001$ & $1.422(1.192-1.695)$ & $<0.0001$ & $1.410(1.187-1.676)$ \\
\hline \multicolumn{5}{|c|}{ Protein Consumption } \\
\hline \multicolumn{5}{|c|}{ Never* } \\
\hline Seldom & 0.046 & $1.449(1.007-2.086)$ & 0.049 & $1.442(1.002-2.074)$ \\
\hline Often & 0.336 & $1.164(0.854-1.588)$ & 0.342 & $1.162(0.852-1.583)$ \\
\hline \multicolumn{5}{|l|}{ Obesity } \\
\hline \multicolumn{5}{|l|}{ Not Obesity* } \\
\hline Obesity & $<0.0001$ & $1.631(1.433-1.856)$ & $<0.0001$ & $1.630(1.433-1.855)$ \\
\hline \multicolumn{5}{|l|}{ Accident History } \\
\hline No* & & & & \\
\hline Yes & $<0.0001$ & $1.488(1.301-1.702)$ & $<0.0001$ & $1.037(1.031-1.043)$ \\
\hline
\end{tabular}

\section{Discussion}

The prevalence of the rheumatic disease in Indonesia based on IFLS data in 2014 is $5.2 \%$. The results showed that there was a significant relationship between age, gender, education, work status, physical activity, and obesity with an increased risk of rheumatic disease. Meanwhile, the multivariate analysis showed that the factors that simultaneously related to an increased risk of rheumatic disease were age, gender, education, physical activity, protein consumption, obesity, and accident history with the greatest PR of 1.686 on the gender variable.

The results showed that there was a significant relationship between age and rheumatic disease. Ayumar and Andi said that rheumatism will increase along with age because the protective layer of joints and its fluid begins to thin and thicken respectively, which makes the body stiff and painful during movement. Furthermore, eight statistical test results showed that with increasing age, the respondents had a 1.056 times greater risk of suffering from rheumatism $(95 \% \mathrm{CI}=1.052$ 1.061) when being controlled by variables which include gender, education, physical activity, dietary, obesity, and accident history. ${ }^{8}$ Toding, et.al, said that people aged $\geq 30$ years old have 5.16 times greater risk of suffering from the rheumatic disease compared to aged $<30$ years $(95 \% \mathrm{CI}=$ 1.33-19.89). ${ }^{9}$ The aging process is considered to be the cause of chondrocytes and the cartilage 
matrix of the joints to decline in function. In addition, there is also ligament weakness, decreased joint strength, and flexibility as well as muscle mass around the joints that support rheumatism. ${ }^{7}$

The results of the bivariate analysis showed that there was a relationship between gender and the incidence of rheumatic disease. This is in accordance with previous research that rheumatism occurs more in women than men. Furthermore, it also showed that women had a 1.632 times greater risk $(95 \% \mathrm{CI}=1.459-1.825)$ of suffering from rheumatism than male respondents. Susarti and Muhammad also stated that female respondents had 4.016 times $(95 \% \mathrm{CI}=1.365-11,817)$ greater risk for suffering from rheumatoid arthritis than male. ${ }^{10}$

Misnadirly stated that women suffer more rheumatism, especially the osteoarthritis type than men. ${ }^{11}$ This is related to the women's hips being wider than that of the men and causes the legs to be closer to the knees, hence the pressure on the knees is not evenly distributed. Furthermore, the muscle mass around women's knees is less. Elsi also mentioned that the female hormone estrogen causes a bad immune system, and affects the autoimmune conditions. ${ }^{12}$

Based on the bivariate analysis, it was reported that there was a relationship between education and the incidence of rheumatic disease. Likewise, the multivariate analysis results showed a relationship between education and the incidence of rheumatic disease after being controlled by variables of age, gender, physical activity, diet, obesity, and accident history. Low level of education increases the risk of suffering from rheumatism by 1.694 times $(95 \% \mathrm{CI}=$ 1.467-1.957). Theoretically, the higher a person's education level, the easier it is to receive all the information needed. ${ }^{13}$ Education is an effort to develop a lifetime lasting personality and abilities inside and outside school. Furthermore, it also affects the learning process, the more educated a person is, the easier it is to get information from other people or the mass media. ${ }^{14}$ The more information received the more knowledge that will be obtained as well as information about rheumatism. In addition, the knowledge gained will also have an impact on changes in diet and lifestyle.

The results of bivariate analysis showed that there was a relationship between work status and the incidence of rheumatic disease, as well as respondents working as protective factors towards the incidence of rheumatic disease $(\mathrm{PR}=0.886 ; 95 \% \mathrm{CI}=0.787-0.999)$. After further analysis, the multivariate results showed that there was no relationship between work status and the incidence of rheumatic disease, and there was no change in PR $>10 \%$ when the job status variable was excluded from the multivariate analysis modeling. Therefore, the work status variable remains excluded because it is not a confounding variable in the incidence of rheumatic disease. Theoretically, in the $\mathrm{CDC}$, jobs involving repetitive knee bends and squats are related to rheumatism incidence. ${ }^{15}$ This disease is commonly reported in heavy physical workers, especially with strength resting on the knees. The prevalence of those suffering from rheumatism was higher 
on port coolers, farmers, and miners than in workers that did not use knee strength, such as the administrative workers.

Physical activity is generally defined as body movements caused by the skeletal muscles which result in energy expenditure. ${ }^{16}$ This is also related to work, where people using knee strength are more likely to suffer rheumatism than those without knee strength. It is also related to the pressure on the knee joint when a person does the strenuous physical activity in that job. Furthermore, excessive pressure on the cartilage of the knee joint will continuously cause scalp degeneration (physical and chemical changes in the cartilage tissue on the knee) and tears that lead to changes in the knee joint cartilage, therefore it is prone to osteoarthritis genu. Meanwhile, according to Susanto, excessiveness causes stiffness in muscles and joints. However, regular and controlled physical activity is still needed in maintaining and helping the muscles to withstand an accept load, and this is one of the important things to prevent rheumatism. ${ }^{17}$

The analysis shows that there is a relationship between moderate physical activity with rheumatic disease incidence, and this is a risk factor for the rheumatism incidence compared to light physical activity. Ayumar and Andiyang said that there is a relationship between health behavior and the incidence of rheumatoid arthritis (p-value 0,000$)$ where the health behavior referred to is physical activity. ${ }^{8}$ However, this study showed no relationship between strenuous physical activity and the incidence of rheumatic disease compared with light physical activity. These results occur due to the recall bias in respondents and when measuring physical activity is only based on that which is conducted by respondents in the last 7 days, hence making them less able to measure the effect of physical activity exposure with the incidence of rheumatic disease. Furthermore, most of the respondents in this study reported that they had conducted the moderate physical activity in the last 7 days. Therefore, the results did not show a significant relationship between strenuous physical activity and the incidence of rheumatic disease.

Protein consumption in this study was seen from the frequency of food containing protein in the form of eggs, fish, and meat in one week by respondents. This is because foods with protein contain purines, which are proteins in the nucleoprotein group. Furthermore, the number of purines causes uric acid/uric crystals buildup in the hands and feet joints. ${ }^{18,19}$ The bivariate analysis results showed no statistically significant relationship between protein consumption and the incidence of rheumatic disease. However, the multivariate analysis results showed a statistically significant relationship between frequent protein consumption and the incidence of rheumatic disease after being controlled by variables of age, gender, education, physical activity, obesity, and accident history. Manullang et. al said that there is a significant relationship between purine consumption and the incidence of rheumatism in the uric acid or gout type. ${ }^{20}$

The results of PR value in this study showed that respondents with frequent protein consumption increased their risk of rheumatic disease by 1.449 times $(95 \% \mathrm{CI}=1.007-2.086)$ 
compared to respondents that had never consumed protein. Manullang, et. Al said that respondents with frequent purines consumption has a 4.139 times greater risk of suffering from rheumatic diseases compared to infrequent consumption $(95 \% \mathrm{CI}=1.726-9.928) .{ }^{20}$

The CDC also stated that obesity is related to osteoarthritis type of rheumatism where it puts more stress on the joints and aggravates the osteoarthritis condition. ${ }^{15}$ The bivariate analysis results in this study reported that there was a relationship between obesity and the incidence of rheumatic disease. This is in accordance with a study from Meliny, Suhadidan Muhammad Sety which shows that BMI is a risk factor for rheumatism. ${ }^{3}$ Furthermore, other studies that also support this research are Mambodiyanto and Susiyadi which stated that there is a relationship between obesity and the incidence of rheumatic osteoarthritis. ${ }^{21}$ This research results reported that obesity increases the risk of rheumatic incidence by 1,612 times $(95 \% \mathrm{CI}=1.417-1.833)$ compared to not obese. The load of joint support increases when a person is overweight or obese, therefore this situation causes mechanical stress and accelerates biochemical changes in joints prone (degeneration). In addition, the excess joint load also triggers damage to cartilages and ligaments and other supporting structures. Therefore, this process occurs when a person is overweight, and the resultant force that needs to fall on the central joint part shifts to the medial part, hence the load received by the joint is not balanced and changes its shape.

Accident history is one of the rheumatic diseases related to stressful or traumatic events such as car accidents, post-traumatic stress disorder (PTSD), repetitive injuries. The majority of rheumatism caused by physical trauma is soft tissue or often referred to as non-articular rheumatism. This type is a condition that describes pain caused by factors outside the joint. ${ }^{15}$

The pathophysiology of this event is that the trauma occurred leads to the accumulation of microtrauma and weakens the collagen cross-link structure. Therefore, triggers denaturation, inflammation, edema, and pain. The weakening of the collagen cross-link structure is due to the process of fibers shedding, the non-collagen matrix, and the vascular elements from the tendons. Trauma also occurs when the ability to regenerate is slower than the stimulus, and the manifestation of this condition is the incidence of non-articular rheumatism. ${ }^{22}$ This study shows that based on bivariate analysis, there is no relationship between accident history and the incidence of rheumatic disease. According to multivariate analysis, the accident history variable had a relationship with the incidence of rheumatic disease after being controlled by age, gender, education, physical activity, diet, and obesity $(\mathrm{PR}=1.479 ; 95 \% \mathrm{CI}=1.293-1.692)$. This means that the rheumatic disease incidence occurs not only because of differences in accident history but multifactorial. Therefore, it can be concluded that the accident history variable is a risk factor after being controlled by the variables of age, gender, education, and obesity. ${ }^{22}$ 


\section{Conclusions}

This research showed that there were $5.2 \%$ of respondents suffering from rheumatism at Indonesia in 2014 based on IFLS data. Furthermore there was a statistically significant relationship between age, gender, education, work status, physical activity and obesity with an increased risk of rheumatic disease. Furthermore, the multivariate analysis results showed that the most dominant and unmodifiable variables that influence the increased risk of rheumatic disease are gender after being controlled by variables of age, education, physical activity, protein consumption, obesity, and accident history. Meanwhile, the most dominant variables with an effect on the increased risk of rheumatic disease are obesity after being controlled by variables of age, gender, education, physical activity, protein consumption, and accident history. It is recommended healthy body weight at a normal BMI needs to be maintained. This is because when the body is overweight and obese, it causes high purine levels in the blood. Efforts to maintain and lose weight can be conducted by eating healthy and low-purine foods, as well as adopting other healthy lifestyles which include appropriate, adequate, and regular physical activity. Screening also needs to be conducted in order to be aware of the rheumatism symptoms.

\section{Acknowledgement}

We grateful to the Faculty of Public Health, Sriwijaya University and all those who have supported and helped carry out this research.

\section{Funding}

There is no funding for this research, and the funds used are the author's personal funds.

\section{Conflict of Interest}

The authors declare that there is no conflict of interest

\section{References}

1. Badan Pusat Statistik. Statistik Penduduk Lanjut Usia 2017. Jakarta, 2018.

2. Kementrian Kesehatan RI. Riset Kesehatan Dasar 2013. Jakarta, 2013.

3. Meliny, Suhadi, Sety M. Analisis Faktor Risiko Rematik Usia 45-54 Tahun di Wilayah Kerja Puskesmas Puuwatu Kota Kendari Tahun 2017. J Ilmu Kesehat Masy 2018; 2: 1-7.

4. Siregar Y. Gambaran Faktor-faktor yang Berhubungan dengan Kejadian Arthritis Rheumatoid pada Lansia di Panti Jompo Guna Budi Bakti Medan Tahun 2014. J Ilmu Keperawatan IMELDA 2016; 2: 104-110.

5. Putri A. Hubungan Jenis Makanan dan Aktivitas Fisik dengan Kejadian Rematik pada Lanjut Usia di Jorong Padang Bintungan di Wilayah Kerja Puskesmas Koto Baru 
Kabupaten Dharmasraya Tahun 2017. Menara Ilmu 2018; 12: 20-26.

6. Adriani M, Wijatmadi B. Pengantar Gizi Masyarakat. Jakarta: Kencana, 2012.

7. Nangi G. Dasar Epidemiologi. Yogyakarta: Deepublish, 2019.

8. Ayumar A, Kasma AY. Faktor-faktor yang Berhubungan dengan Kejadian Arthritis Rheumatoid pada Lansia di Puskesmas Tompobulu kabupaten Gowa. J Mitra Sehat 2016; 6: 869-878.

9. Toding MN. Analisis Faktor Risiko Kejadian Gouthy Arthritis di Wilayah Kerja Puskesmas Bahu Kota Manado Tahun 2015. J Ikmas 2015; 1: 1-6.

10. Susarti A, Romadhon M. Faktor-faktor yang Berhubungan dengan Kejadian Rheumatoid Arthritis pada Lansia. Jurnal Aisyiyah Medika. J Aisyiyah Med 2019; 4: 284-295.

11. Misnadirly. Osteoartritis: Penyakit Sendi pada Orang Dewasa dan Anak. Jakarta: Pustaka Populer Obor, 2010.

12. Elsi M. Gambaran Faktor Dominan Pencetus Arthritis Rheumatoid di Wilayah Kerja Puskesmas Danguang Danguang Payakumbuh Tahun 2018. Menara Ilmu; 12.

13. Notoatmodjo. Pengantar Pendidikan Kesehatan Ilmu Perilaku. Yogyakarta: Andi Offset, 2003.

14. Silaban N. Gambaran Pengetahuan Penderita Rematik tentang Perawatan Nyeri Sendi di Dusun I Desa Sunggal Kanan Kecamatan Sunggal Kabupaten Deli Serdang Tahun 2015. J Ilmu Keperawatan IMELDA 2016; 2: 46-55.

15. CDC. Arthritis: Risk Factors. CDC, https://www.cdc.gov/arthritis/basics/risk-factors.htm (2018, accessed 18 January 2019).

16. Merita, Aisah, Aulia S. Status Gizi dan Aktivitas Fisik dengan Status Hdrasi pada Remaja di SMA Negeri 5 Kota Jambi. J Ilmu Kesehat Masy 2018; 9: 207-215.

17. Susanto. Penanggulangan Penyakit Rematik. Jakarta: Salemba Medika, 2008.

18. Smeltzer. Buku Ajar Keperawatan Medikal Bedah. 8 Volume 3. Jakarta: EGC, 2011.

19. Nasution HA. Hubungan Gaya Hidup Lansia dengan Kejadian Nyeri Rheumatoid Arthritis di Desa Buket Selamat Kecamatan Sungai Raya Kabupaten Aceh. J Keperawatan STIKES Bina Nusant 2017; 170-178.

20. Manullang I. Faktor-faktor yang Berhubungan dengan kejadian Asam Urat (Gout) pada Usia $\geq 45$ tahun di Desa Ujung Serdang Kecamatan Tanjung Morawa Tahun 2016. J Gizi, Kesehat Reproduksi dan Epidemiol 2016; 1: 1-9.

21. Mambodiyanto, Susiyadi. Pengaruh Obesitas Terhadap Osteoartritis Lutut pada Lansia di Kecamatan Cilacap Utara Kabupaten Cilacap. J Sainteks 2016; 13: 1-10.

22. Kalim. Reumatologi Klinik. Malang: UB Press, 2019. 